\title{
Peningkatan Persepsi Kecukupan ASI Pada Ibu Menyusui
}

\author{
Ratih Sakti Prastiwi ${ }^{1}$, Meyliya Qudriani ${ }^{2}$, Iroma Maulida ${ }^{3}$, Novia Ludha ${ }^{4}$, Riska Arsita ${ }^{5}$ \\ 1,2,3,4,5 Diploma III Kebidanan Politeknik Harapan Bersama \\ e-mail: ratih.sakti@ymail.com
}

\begin{abstract}
Abstrak
Capaian ASI Eksklusif di Indonesia masih jauh dari target yang ditetapkan pemerintah. Pada tahun 2016 cakupan ASI Eksklusif mengalami penurunan dimana pada tahun 2013 capaian mencapai 38\% menjadi 29.5\%. Salah satu faktor yang mempengaruhi keberhasilan ASI Eksklusif adalah persepsi ibu menyusui akan kecukupan ASI-nya. Kegiatan pengabdian masyarakat ini dilakukan untuk meningkatkan persepsi ibu menyusui tentang kecukupan produksi ASI. Kegiatan dilakukan dengan memberikan pendidikan kesehatan seputar ASI Eksklusif, penilaian kecukupan ASI, faktor yang mempengaruhi produksi ASI, Cara peningkatan produksi ASI. Kegiatan ini diberikan kepada ibu menyusui yang bayinya berusia 0-6 bulan sehingga secara langsung dapat membantu peningkatan angka capaian ASI Eksklusif untuk wilayah Margadana. Setelah dilakukan pendidikan kesehatan, terdapat peningkatan pengetahuan ibu tentang kecukupan ASI sebesar 3.32 point. Hal ini menunjukkan penyuluhan merupakan salah satu cara membantu masyarakat untuk merubah sikap dan perilakunya untuk lebih sehat secara mandiri.
\end{abstract}

Kata kunci-ASI Eksklusif, Persepsi, Menyusui

\section{PENDAHULUAN}

ASI Eksklusif merupakan salah satu program pemerintah yang dicanangkan untuk menurunkan angka mortalitas dan morbiditas bayi. ASI Eksklusif dapat meningkatkan status gizi bayi yang secara langsung berpengaruh pada peningkatan status gizi di masyarakat. Cakupan ASI Eksklusif di Indonesia mengalami penurunan dan masih jauh dari capaian yang ditetapkan. Pada tahun 2013 cakupan ASI Eksklusif mencapai 38\% dan pada tahun 2016 turun menjadi 29.5\%. Cakupan ASI Eksklusif di Jawa Tengah sendiri mencapai 42,7\%. Kota Tegal merupakan salah satu kabupaten/ kota madya yang memiliki cakupan Asi Eksklusif yang rendah yaitu 23.8\%. Data yang didapatkan dari Puskesmas margadana tahun 2016, terdapat bayi di Margadana sebanyak 215 bayi. Dimana dari 215 bayi tersebut hanya $59.1 \%$ (127 bayi) yang mendapatkan ASI Eksklusif, 18.1\% (39 bayi) masih dalam tahapan pemberian ASI eksklusif dan 22.8\% (49 bayi) tidak mendapatkan ASI Eksklusif. Capaian tersebut sangat jauh dari target nasional yaitu $85 \%{ }^{1,2}$.

Pemberian ASI eksklusif selama 6 bulan ini merupakan hak anak sebagaimana tercantum dalam Kepmenkes RI No.450/Menkes/SK/IV dan Undang - undang Kesehatan No. 36 tahun 2009 pasal 128 ayat 1 yang berbunyi, "Setiap bayi berhak mendapat air susu ibu eksklusif sejak dilahirkan selama 6 (enam) bulan, kecuali atas indikasi medis". Selain itu, pemberian ASI Eksklusif telah dicanangkan oleh Organisasi Kesehatan Dunia atau WHO sejak tahun 2011. WHO merekomendasikan agar bayi mendapatkan ASI Eksklusif hingga usia 6 bulan. Baru setelah usia 6 bulan, bayi dapat diberi makanan pendamping ASI (MPASI) dengan tetap memberikan ASI hingga 2 tahun $^{2,3}$.

Air susu ibu (ASI) merupakan makanan terbaik bagi bayi untuk usia 6 bulan pertama kehidupannya. Pemberian ASI Eksklusif selama 6 bulan dilakukan dengan pertimbangan dimana sistem imun bayi kurang dari 6 bulan belum sempurna. Pada usia 6 bulan pertama, sistem pencernaan bayi belum matang sehingga membutuhkan asupan yang mudah dicerna 
seperti ASI. Apabila bayi mendapatkan tambahan makanan lebih dini akan membuka peluang bakteri atau kuman masuk terutama yang berasal dari makanan yang disajikan tidak higienis ${ }^{4,5}$.

Hasil penelitian Prabasiwi et. al. (2015) menyebutkan bahwa salah satu penyebab kegagalan pemberian ASI Eksklusif adalah karena ibu menyusui merasa ASI-nya tidak cukup untuk memenuhi kebutuhan bayinya. Sebanyak 35\% ibu memberikan makanan tambahan pada bayi sebelum usia 6 bulan karena adanya persepsi ketidak cukupan ASI. Beberapa faktor yang mempengaruhi pembentukan persepsi tersebut adalah kurangnya pengetahuan ibu mengenai ASI Eksklusif terutama kecukupan ASI bagi bayinya ${ }^{2}$.

Pengetahuan merupakan hasil dari tahu dan terjadi setelah orang melakukan penginderaan terhadap suatu objek tertentu. Apabila perilaku dilakukan melalui proses yang didasari oleh pengetahuan, kesadaran dan sikap yang positif, maka perilaku tersebut akan bersifat langgeng. Apabila ibu menyusui memahami mengenai tanda kecukupan ASI, jenis makanan yang merangsang produksi ASI, serta waktu pemberian ASI bagi bayi maka akan mempengaruhi keberlanjutan pemberian ASI Eksklusif tersebut ${ }^{2}$.

Tidak adekuatnya pemberian ASI kepada bayi selama masa neonatus hingga usia 6 bulan, sangat mempengaruhi perkembangan dan pertumbuhan bayi. Pemberian makanan pendamping ASI sebelum usia 6 bulan juga memiliki resiko pada peningkatan angka morbiditas dan mortalitas bayi. Tingkat pengetahuan ibu yang kurang, sangat mempengaruhi perilaku ibu dalam pemberian ASI. Meskipun telah ada Kelompok Pendukung ASI di Margadana, namun hingga saat ini belum ada perubahan perilaku pemberian ASI Eksklusif. Oleh karena itu perlu adanya kegiatan peningkatan persepsi ibu menyesui tentang kecukupan ASI.

\section{METODE}

Kegiatan Pengabdian kepada masyarakat peningkatan persepsi kecukupan ASI pada ibu menyusui ini dilakukan kepada ibu menyusui di wilayah Margadana yang memiliki bayi usia $0-6$ bulan. Kegiatan diawali dengan survey lapangan untuk mencari jumlah ibu menyusui yang bayinya dalam rentang usia $0-6$ bulan dan didapatkan sebanyak 22 peserta.

Peningkatan persepsi ibu menyusui dilakukan dengan meberikan pendidikan kesehatan berupa pemberian materi tentang ASI Eksklusif, penilaian kecukupan ASI, faktor yang mempengaruhi produksi ASI serta melatih cara peningkatan ASI khususnya melalui perawatan payudata dan pijat oksitosin. Kegiatan pengabdian kepada masyarakat dilaksanakan selama 2 hari yaitu pada tanggal 8-9 Mei 2017 bertempat di rumah kader wilayah kerja Puskesmas Margadana. Hal ini dilakukan dengan pertimbangan penyuluhan yang dilakukan dalam kelas kecil akan lebih meningkatkan penerimaan materi yang diberikan. Tim Pelaksana dapat secara langsung memantau peserta pada saat praktek.

Adapun secara rinci kerangka pemecahan masalah persepsi kecukupan ASI dapat dilihat pada gambar 1 .

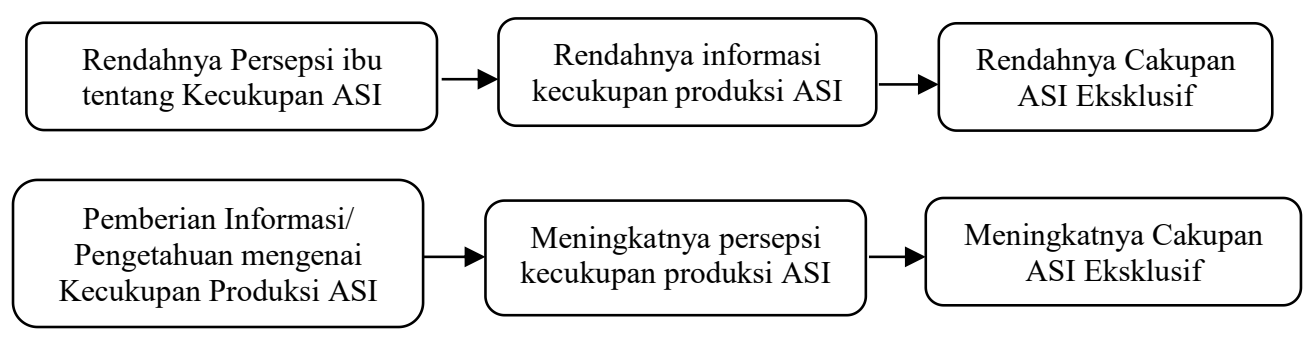

Gambar 1 Kerangka Pemecahan Masalah

\section{HASIL DAN PEMBAHASAN}

Kegiatan pengabdian masyarakat peningkatan persepsi ibu menyusu tentang kecukupan ASI dilaksanakan selama 2 hari berturut-turut. Kegiatan ini diawali dengan 
menanyakan sejauh mana pengetahuan ibu mengenai ASI Eksklusif. Mayoritas ibu dalam kegiatan ini telah mengetahui bahwa ASI Eksklusif merupakan pemberian ASI selama 6 bulan tanpa memberikan makanan atau cairan apapun selain ASI kecuali vitamin atau obat-obatan yang diberi dari Puskesmas. Setelah melakukan persamaan persepsi mengenai ASI Eksklusif, kemudian ibu diberikan pemahaman mengenai apa yang dimaksud dengan kecukupan ASI. Dalam kegiatan tersebut pemateri menjelaskan tanda-tanda kecukupan ASI yang dapat dinilai atau dilihat dari kondisi bayi. Adapun tanda kecukupan ASI meliputi peningkatan berat badan bayi, pola eliminasi bayi (BAK/BAB), perilaku bayi saat menyusu dan setelah menyusu. Usai pemberian pemahaman kecukupan ASI kemudian pemateri memberikan pemahaman mengenai bagaimana cara untuk meningkatkan produksi ASI seperti pola istirahat ibu, asupan nutrisi, dukungan keluarga, dan teknik menyusui yang benar.

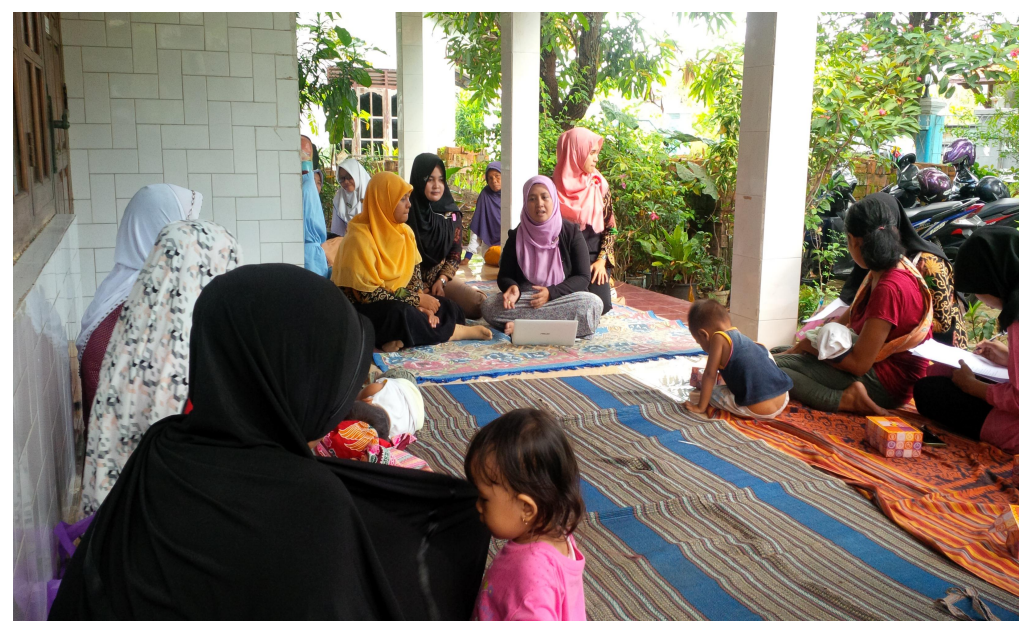

Gambar 2. Pemberian Materi Kecukupan ASI

Ibu menyusui juga diajarkan mengenai bagaimana melakukan perawatan payudara dan pijat oksitosin. Dimana dengan melakukan perawatan dan pijat oksitosin membantu melancarkan produksi ASI. Dalam mengajarkan ibu perawatan dan pijat oksitosin, pemateri dibantu oleh mahasiswa dengan tujuan ibu menyusui lebih memahami dan merasakan seperti apa praktek yang benar. Tim Pelaksana Pengabdian Pada Masyarakat melibatkan mahasiswa dalam kegiatan ini dengan tujuan agar mahasiswa dapat secara langsung mempraktekkan pemberian pendidikan kesehatan kepada masyarakat serta memahami fenomena atau permasalahan yang sering dijumpai oleh masyarakat khususnya tentang ASI Eksklusif.

Pemberian pendidikan kesehatan tersebut ditujukan untuk meningkatkan efikasi ibu untuk memberikan ASI Eksklusif. Efikasi ibu dipengaruhi beberapa faktor salah satunya adalah persepsi kecukupan ASI. Hal ini didukung oleh hasil penelitian Prabasiwi (2015) dimana persepsi dapat dipengaruhi kurangnya pengetahuan atau informasi. Sebanyak $51.1 \%$ ibu menyusui di Margadana dan Tegal Selatan memiliki persepsi kecukupan asi yang rendah dan sebanyak 58.6\% memiliki pengetahuan yang kurang mengenai produksi ASI dan asupan energi yang dibutuhkan ibu menyusui. Dengan memberikan pemahaman mengenai apa yang dimaksud dengan kecukupan ASI dan bagaimana untuk meningkatkan produksinya maka akan tumbuh kepercayaan diri untuk mampu memberikan ASI secara Eksklusif.

Peningkatan pemahaman mengenai kecukupan ASI dilakukan Tim pelaksana dengan memberikan materi seputar tanda kecukupan ASI seperti adanya kenaikan berat badan pada bayi. Umumnya bayi pada 1-2 minggu pertama akan mengalami penurunan yang kemudian mulai mengalami peningkatan 2-3 kali lipat dari berat badan lahir saat bayi menginjak usia 3-4 bulan. Tanda lainnya dapat dilihat dari frekuensi bayi menyusu, dalam sehari bayi minimal menyusu setiap 2-3 jam atau 8-12 kali. Frekuensi buang air kecil minimal 6 kali per hari dan buang air besar 3 kali per hari. Bayi yang menyusu dengan pelekatan yang baik dan benar akan menimbulkan rasa nyaman dan tidak rewel ${ }^{6,7}$.

Selain itu, ibu menyusui juga diberi pengetahuan mengenai faktor yang mempengaruhi produksi ASI seperti dengan menjaga kondisi psikologis ibu menyusui, 
kondisi psikologi seperti stress atau depresi dapat berpengaruh pada produksi oksitosin. Oksitosin merupakan salah satu hormon yang dapat merangsang prolactin untuk terus memproduksi ASI. Untuk mengoptimalkan kondisi psikologis ibu, ibu perlu istirahat yang cukupminimal 8 jam pad malah hari. Dukungan keluarga juga sangat berpengaruh dalam menjaga kondisi ibu. Dukungan keluarga dapat menurunkan rasa khawatir ibu, dukungan dapat ditunjukkan dengan membantu mengurus dan merawat bayi, membantu pengambilan keputusan terkait dengan ASI Eksklusif. Ibu menyusui juga perlu menjaga asupan nutrisinya. Hasil penelitian yang dilakukan oleh Prabasiwi (2015) menunjukkan ibu menyusui yang menjaga asupan $>2200 \mathrm{kkal} / \mathrm{hari}$ dapat menimbulkan rasa percaya diri bahwa produksi ASI nya akan terpenuhi. Normalnya ibu yang menyusui perlu meningkatkan asupan 300-500 kkal dari asupan biasanya. Salah satu upaya pemenuhan nutrisi ibu menyusui adalah dengan menjaga intake minum. Konsumsi air putih harus dilakukan minimal 8-10 gelas per hari agar tidak timbuh dehidrasi pada ibu. Apabila ibu menyusui kurang intake minumnya maka akan berpengaruh terhadap produksi ASI menjadi lebih sedikit. Untuk menjaga intake air dalam tubuh, ibu menyusui juga perlu mengkonsumsi buah dan sayuran yang mengandung kadar air tinggi seperti brokoli, semangka, melon, dan sebagainya ${ }^{2,7,8}$.

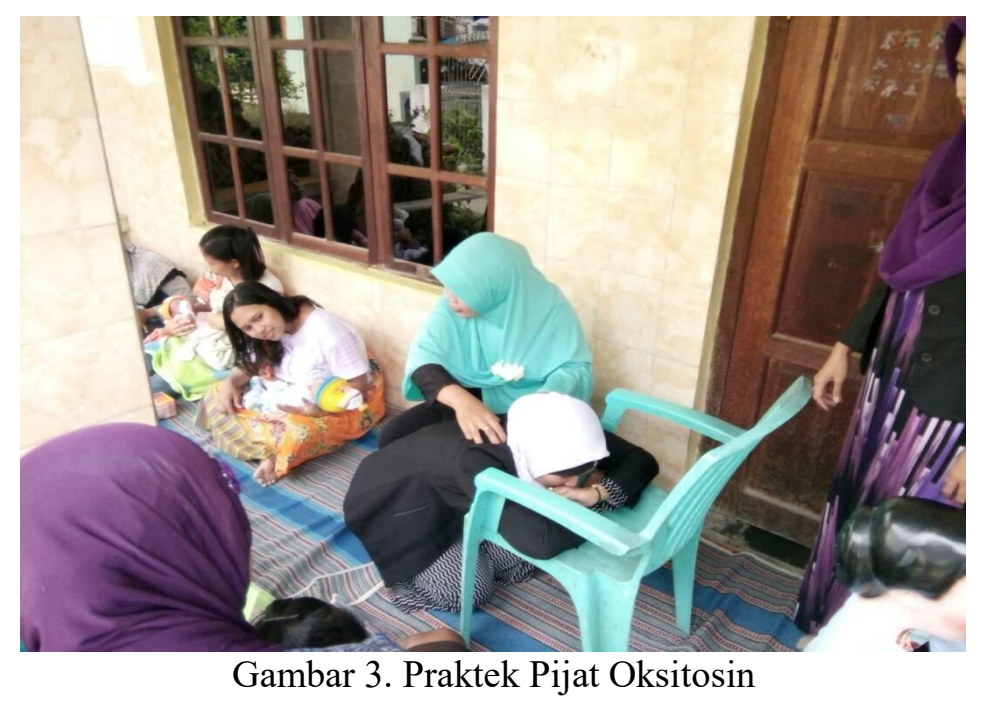

Produksi ASI dapat terus meningkat apabila ibu terus menyusui bayinya. Kondisi payudara yang kosong akan merangsang bagian otak untuk memproduksi hormon oksitosin dan prolaktin agar memproduksi ASI. Ibu menyusui juga harus menghindari penggunaan botol atau empeng pada bayi. Hal ini dapat menimbulkan bayi bingung puting. Isapan bayi yang menggunakan botol atau empeng tidak akan sekuat dengan bayi yang menyusu dengan payudara ibu. Peningkatan produksi ASI juga dapat dibantu dengan melakukan pijat oksitosin. Pijatan ini menimbulkan rasa nyaman pada ibu sehingga reflek letdown akan merangsan produksi oksitosi. Pijat oksitosin ini dilakukan dengan melakukan pijatan sepanjang vertebrata $\mathrm{ibu}^{9}$. Tim melakukan praktik pemijatan menggunakan panthom tubuh agar ibu menyusui dapat melihat dengan jelas area yang harus dpijat dan bagaimana cara memijatanya. Selain pijat oksitosin, ibu juga dilatih untuk breast care. Salah satu permasalahn yang paling sering ditemui oleh ibu menyusui adalah adanya bendungan ASI (engorgement). Bendungan disebabkan produksi Asi yang penuh namun tidak disusukan/ diperah. Breast care dilakukan dengan memijit area payudara hingga ASI keluar. Teknik ini juga dapat dilakukan oleh ibu menyusui yang ingin memerah ASI-nya namun tidak memiliki alat bantu perah ${ }^{8,9}$. 


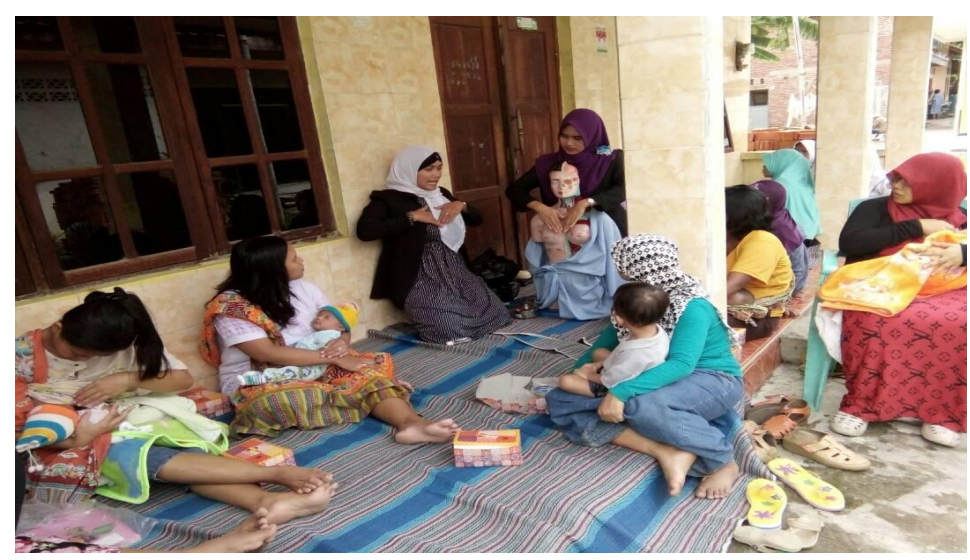

Gambar 4. Praktek Perawatan Payudara

Dengan diberikannya pemaham kepada peserta, peserta lebih mengerti bagaimana mereka memantau bahwa bayinya mendapatkan ASI yang cukup. Pemahaman ibu menyususi terhadap materi yang diberikan ditunjukkan dari adanya peningkatan pengetahuan sebelum dan sesudah diberi materi. Sebelum pemberian materi, ibu menyusui diberikan kuesioner pengetahuan tentang kecukupan ASI, satu bulan setelah materi, ibu kembali dikumpulkan untuk mengisi kuesioner tersebut. Tim melakukan pengambilan data setelah satu bulan dari pemberian pendidikan kesehatan dikarenakan Tim ingin mengetahui bagaimana ibu menyusui mempraktekkan materi tersebut di rumah. Hasil analisis statistik didapatkan

Tabel 1. Perbedaan tingkat pengetahuan ibu tentang kecukupan ASI

\begin{tabular}{|l|c|c|}
\hline & Mean & Std Deviation \\
\hline Pengetahuan sebelum & 6,27 & 2,763 \\
\hline Pengetahuan sesudah & 9,59 & 1.790 \\
\hline
\end{tabular}

Peningkatan pemahaman ibu mengenai kecukupan ASI terlihat dari adanya peningkatan rata-rata nila sebesar 3.32. Hal ini menunjukkan adanya keberhasilan tim dalam menyampaikan informasi kepada ibu menyusui. Pengetahuan seseorang paling banyak diterima melalui indera pandang yaitu sebesar 75\%-85\% sedangkan melalui indera pendengaran sebesar $13 \%$ dan indera lainnya $12 \%$. Pada kegiatan pengabdian masyarakat ini, informasi kesehatan diberikan tidak hanya melalui ceramah saja tetapi juga dengan metode praktek. Dengan mempraktekkan langsung, ibu menyusui lebih aktif selama penyuluhan. Pada saat praktek, indera pandang dan pendengaran akan bekerja sehingga penerimaan pengetahuan lebih optimal ${ }^{10,11}$.

Sedangkan penyuluhan dalam bentuk ceramah cenderung menimbulkan rasa bosan, sehingga peserta penyuluhan lebih pasif dan sering tidak konsentrasi. Hal tersebut dapat menyebabkan informasi tidak diterima secara menyeluruh. Pernyataan tersebut senada dengan hasil penelitian Merdhika et. al. (2014) yang menyatakan bahwa pengetahuan seseorang dapat dipengaruhi oleh faktor sosial budaya dan lingkungan tempat tinggalnya sehingga mempengaruhi seseorang dalam berperilaku sehat. Dengan adanya intervensi berupa pendidikan kesehatan mampu meningkatkan sikap seseorang terhadap perilaku sehat ${ }^{11,12}$.

\section{KESIMPULAN}

Pendidikan kesehatan merupakan salah satu upaya yang tepat untuk menyebar luaskan informasi kesehatan kepada masyarakat. Dengan diberikannya pendidikan kesehatan maka akan terbentuk sikap positif terhadap kesehatan yang secara langsung mempengaruhi masyarakat dalam berperilaku sehat. Tujuan kegiatan peningkatan persepsi kecukupan ASI pada ibu menyusui tepat dimana ibu yang sedang menyusui bayinya yang masih usia 0-6 bulan sehingga secara langsung dapat membantu peningkatan angka capaian ASI Eksklusif 
untuk wilayah Margadana. Dengan adanya keterlibatan dalam pemberian informasi kecukupan ASI dapat dilanjutkan kepada ibu menyusui lainnya melalui kegiatan kemasyarakatan salah satunya posyandu.

\section{SARAN}

Untuk mencapai target ASI Eksklusif, pendidikan kesehatan juga perlu diberikan kepada keluarga. Hal tersebut perlu dilakukan karena efikasi ibu menyusui dapat dipengaruhi juga dari motivasi keluarga. Selain itu untuk mendukung program ASI Eksklusif, perlu adanya pelatihan bagi kader agar dapat meneruskan informasi dan membantu pemantauan ASI Eksklusif di wilayanya.

\section{UCAPAN TERIMA KASIH}

Penulis mengucapkan terima kasih kepada Puskesmas Margadana yang telah memberikan izin dan memfasilitasi kegiatan pengabdian masyarakat ini. Terimakasih kami ucapkan kepada Kader yang telah membantu dan memfasilitasi responden pengabdian masyarakat dan tim pelaksana kegiatan pengabdian masyarakat. Kepada para peserta pengabdian masyarakat yang telah bersedia turut aktif dalam kegiatan ini.

Terimakasih tidak lupa kami ucapkan kepada Politeknik Harapan Bersama yang telah memfasilitasi pendanaan dan perijinan pelaksanaan kegiatan ini. Terimakasih kami ucapkan kepada ketua program studi Diploma III Kebidanan yang telah mendukung kegiatan ini. Kepada mahasiswa-mahasiwa ku tercinta yang telah terlibat aktif dalam memberikan pendidikan kesehatan. Semoga ilmu yang kalian dapatkan dapat bermanfaat di masyarakat.

\section{DAFTAR PUSTAKA}

[1] Pusat Data dan Infomasi Kementerian Kesehatan RI. 2017. Data dan Informasi Profil Kesehatan Indonesia 2016. Jakarta: Pusat Data dan Infomasi Kementerian Kesehatan RI

[2] Prabasiwi A, Fikawati S, Syafiq A. 2015. ASI Eksklusif dan Persepsi Ketidakcukupan ASI. Kesmas, 9(3): 282-287

[3] Prastiwi R, Maulida I, Octaviana T. (2015). Studi Fenomenologi: Memerah dan Menyimpan ASI Perah. Prosiding Pertemuan Ilmiah Internasional Bidan 2015, Jakarta7-9 Oktober 2015

[4] Maryunani A. (2012). Inisiasi Menyusu Dini, ASI Eksklusif dan Manajemen Laktasi. Jakarta: CV Trans Info Media

[5] Fikawati S. Syafiq A. (2009). Penyebab Keberhasilan dan Kegagalan Praktik Pemberian ASI Eksklusif. Jurnal Kesehatan Masyarakat Nasional, 4(3): 120-131

[6] Rahayu R, Andriani A. (2014). Metode Memperbanyak Produksi ASI Post Sectio Caesarea dengan Tehnik Marmet dan Breast Care di RSUD Karanganyar. Gaster, $\mathrm{XI}(12): 56-58$

[7] Suryani E, Astuti E. (2013). Pengaruh Pijat Oksitosin Terhadap Produksi ASI Ibu Postpartum di BPM Wilayah Kabupaten Klaten. Jurnal Terpadu Ilmu Kesehatan, 2(2): 123-128

[8] Astuti I. (2013). Determinan Pemberian ASI Eksklusif pada Ibu Menyusui. Jurnal Health Quality, 4(1): 60-68

[9] Wijayanti L. (2014) Pengaruh Pijat Oksitosin Terhadap Produksi ASI Pada Ibu Postpartum di Puskesmas Mergangsan Yogyakarta Tahun 2014. Naskah Publikasi. Yogyakarta: STIKES ‘Aisyiyah Yogyakarta 
[10] Wirawan S, Abdi L, Sulendri NK. (2014). Penyuluhan dengan Media Audio Visual dan Konvensional Terhadap Pengetahuan Ibu dan Anak Balita. Jurnal Kesehatan Masyarakat, 10(1): 80-87

[11] Handayani dan Rahmawati. (2009). Pengaruh Frekuensi Penyuluhan di UKGS pada Anak SD terhadap Derajat Pengetahuan Kesehatan Gigi dan Mulut. Mutiara Medika, 9(2): 46-51

[12] Merdhika W, Mardji, Devi M. (2014). Pengaruh Penyuluhan ASI Eksklusif terhadap Pengetahuan Ibu tentang Asi Eksklusif dan Sikap Ibu Menyusui di Kecamatan Kanigoro Kabupaten Blitar. Teknologi dan Kejuruan, 37(1): 65-72 